\title{
Lysimeter Simulation of Paddy Straw Landfill Bioreactor for Optimum Gas Production
}

\author{
Center for Renewable Energy Sources \\ Postgraduate Institute of Agriculture \\ University of Peradeniya \\ Peradeniya
}

D.A.S. Gamage, G.W.N.L. Sarachchandra, B.F.A. Basnayake and W.A.J.M. Costa ${ }^{1}$

\begin{abstract}
Biogas technology plays a vital role in supplying the energy demand. There is a possibility to generate biogas from paddy straw using landfill bioreactors, rather than employing expensive anaerobic digesters. This study was carried out to determine possible avenues to produce biogas from agricultural wastes. The study attempted to maximize the methane emission from a mixture of paddy straw, cow dung and green materials in landfill bioreactor simulated lysimeter. The lysimeter consisted of a clay-polythene-clay liner gas collection system, leachate recirculation system, and the main reactor. The lysimeter performances were evaluated by analyzing $\mathrm{pH}$, Biochemical Oxygen Demand (BOD), Total Dissolved Solids (TDS), Total Solids (TS), Total Suspended Solids (TSS), Volatile Solids (VS), Volatile Suspended Solids (VSS), Organic Carbon (OC), Brix, ammonium nitrogen and nitrate nitrogen. Recirculation of leachate, addition of water to the system and fabrication of clay-polythene-clay liner showed positive effects on gas production. In the leachate, TS, VS, TSS and VSS changed in a cyclic manner due to the microbial growth pattern in the lysimeter. There was high $\mathrm{pH}$ reduction in the first week, indicating the start of the hyrolysis phase. Primary settlement rate of lysimeter was very high and it reduced to $50 \mathrm{~cm}$ during 17 days. The BOD concentrations decreased over the course of 63 days and this may be due to slow release and hydrolysis of organics from the straw into leachate. Moreover, lack of recirculation also may have contributed to reduction of anaerobic process. During the experimental period, the organic carbon content and Brix gradually decreased. The removal of prognating anaerobic digestion process was rapid and produced biogas. Therefore, there is a high potential to harness biogas from landfill bioreactors using paddy straw together with other agricultural wastes, while achieving environmental friendly waste disposal method under Sri Lankan conditions.
\end{abstract}

\section{INTRODUCTION}

The power consumption in Sri Lanka is increasing with the population growth. The present generation of power in the country is not enough to fulfill the demand. To overcome the issue, conversion of agricultural crop residues and other biological by-products into an energy source is an appropriate option. Although there are few methods available for paddy straw reuse, such as animal feed, paper making, packing materials, growing mushrooms, a significant amount of paddy straw remains unused and burned in open fields, causing serious environmental and health problems. The concept of manufacturing biogas using paddy straw is practicable in Sri Lanka, where more than $40 \%$ of the farmers are engaged in paddy

Department of Crop Science, Faculty of Agriculture, University of Peradeniya Peradeniya 
cultivation producing 4.1million metric tons of paddy (Department of Census and Statistics, 2008) of paddy resulting in almost the same amount of paddy straw annually (Champaign et al., 1999).

Landfill bioreactors are the most popular method to produce biogas in the world due to the easiness of the operation and maintenance (Warith et al., 2005). Other anaerobic digester systems are expensive to construct and difficult to maintain compared to landfill bioreactors. The landfill bioreactor shows long term biogas production due to the natural balance occurring in the reactor. In addition, there is no unfavorable odor released in the landfill bioreactor due to proper covering of it. The landfill bioreactor can hold a large quantity of waste than other anaerobic digesters. One of the main advantages of the landfill bioreactors is that, the composted material can be utilized as fertilizer once the biogas generation ceases.

Research shows that the majority of soils in main rice growing areas are low in organic matter (Wickramasinghe and Wijewardena, 2003). Under such conditions, retention of plant nutrients is low. In general, organic manures are useful in conserving soil fertility. Rice straw, animal manure, green manure, city waste and crop waste could be used as sources of organic manure to maintain the organic matter content in soil (Wijewardena, 1993; 2000).

When incorporating straw into soil as a practice, there is a promotion of methane $\left(\mathrm{CH}_{4}\right)$ generation. The application of rice straw substantially increases $\mathrm{CH}_{4}$ emission rates (Yagi and Minami, 1990). Therefore, adding humidified substrates such as compost is better than direct application of straw into the field (Schutz et al., 1989).

Production of biogas using paddy straw will satisfy most of the energy demand of the country and also prevent environmental pollution caused by gasoline and reduce the methane generation from paddy fields. Agricultural wastes such as paddy straw are renewable energy sources and a highly valued organic fertilizer. Thus, converting paddy straw into energy would benefit farmers as well as other communities in the country. In this context, the main objective of this study was to design and test a lysimeter simulation of a landfill bioreactor to generate biogas (methane) using paddy straw, animal manure and green manure.

\section{METHODOLOGY}

\section{Experimental site}

The lysimeter was designed at the Solid Waste Management Research Unit (SWMRI), in the Department of Agricultural Engineering, University of Peradeniya. Estimation of methane emission and evaluation of the performances of the lysimeter was conducted at Meewathura University farm, Department of Agricultural Engineering. Laboratory testing was carried out at the Agricultural Biotechnology Center and at the Department of Agricultural Engineering.

\section{Design of the lysimeter}

The objective of designing of the clay-polythene-clay liner was to ensure leachate purification so that the leachate would not affect the environment. Leachate filters through the lining materials and is purified. Combination of the clay-polythene-clay liners is important for the purification process. Mixture of clay-polythene is a biofilm (Gunarathna et al., 2007). For purifying the leachate, the hydraulic conductivity of these liners is important. 
Hydraulic conductivity was measured at two different heights. Constant water head was maintained until the hydraulic conductivity was measured. In this system, recirculation was done at two different heights as such, the recirculation pipes were placed at the top and middle of the lysimeter. Leachate was recirculated through the middle pipe and the rainfall water and leachate were added from the top pipe. Valves were used to change the leachate recirculation pathway. The top pipe was placed $3 \mathrm{~m}$ rom the top of the clay-polythene-clay liner and the middle one was placed $1.5 \mathrm{~m}$ above the liner.

\section{Operational procedure of lysimeter}

\section{Steps of feeding the lysimeter}

Initially, the leachate collecting pipes were placed and then straw was placed with water and compacted. Straw was placed up to $27 \mathrm{~cm}$ height from the liner and then cow dung was applied as a $3 \mathrm{~cm}$ layer. Prior to that, water was added to the cow dung at 1:1 ratio. Then more straw was placed with water and compacted. Altogether $431 \mathrm{~kg}$ of straw and water were added for compacting the straw at 1:1 ratio. Straw was filled up to the top leachate recirculation pipe and then green materials were added. Top recirculation pipe was placed after that. Then the settlement measuring rod was placed and lysimeter was closed by a cap.

\section{Fabrication of temperature sensors and gas collecting system in lysimeter}

The gas emission system required the use of two perforated pipes. The placing of those pipes was in the middle of the lysimeter at two different heights. The first one was installed $50 \mathrm{~cm}$ above the bottom liner and rose to the top of the lysimeter. The second one was placed from the middle and rose to the top of the lysimeter. The fabrication of sensors was done with LM35 transistors and they were covered with metal caps and wires were covered by flexible PVC pipes. These sensors were placed on the top of the bottom clay-polythene-clay liner, 3 $\mathrm{m}$ above the clay-polythene-clay liner and the final one was placed on the gas chamber. Fig. 1 shows the sketch of Lysimeter design. 


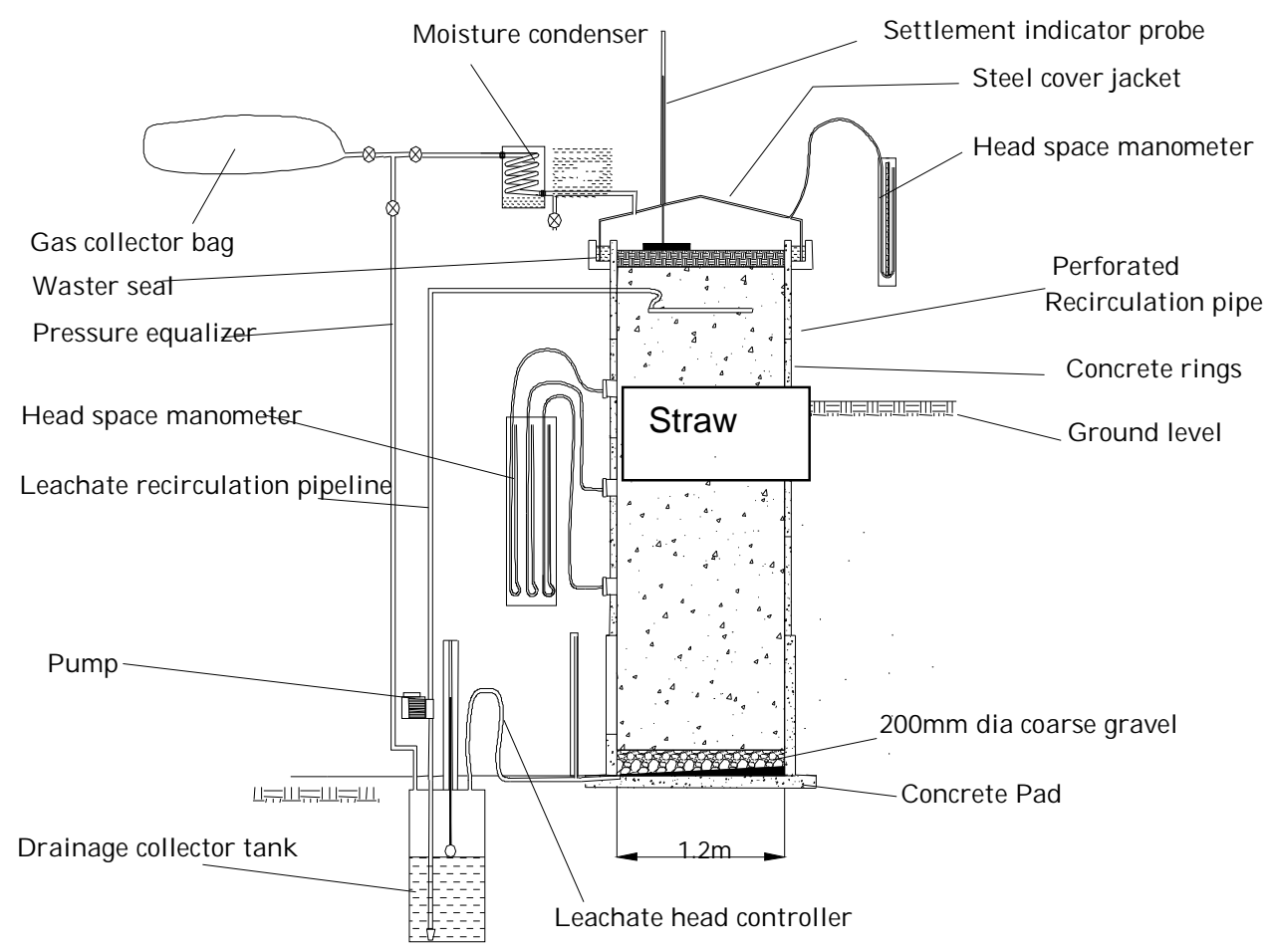

Fig. 1. Sketch of Lysimeter design

\section{Laboratory analysis}

Table 1. Analyzed Parameters and Standard Test Methods

\begin{tabular}{|c|c|c|}
\hline Analytical Parameter & Method & Instrument \& Condition \\
\hline$\overline{\mathrm{pH}}$ & $\mathrm{pH}$ meter & Lonalyzer (model 407) \\
\hline Total Dissolved Solids (TDS) & & Thermo orient Model 145A \\
\hline Electrical conductivity & & Thermo orient Model 145A \\
\hline Total Solids (TS) Volatile Solids (VS) & APHA Method 2540-G. & \\
\hline Total Suspended Solids (TSS) & APHA Method 2440-D. & \\
\hline Volatile Suspended Solids (VSS) & APHA Method 2440-E. & \\
\hline Sugar content (Brix) & & $\begin{array}{l}\text { ATAGON-IE BRIX 0 32\% } \\
\text { Hand Refractometer }\end{array}$ \\
\hline Biological Oxygen Demand (BOD) & Winkler Procedure & \\
\hline Organic Carbon & $\begin{array}{l}\text { Nelson and Sommers } \\
\text { (1982) }\end{array}$ & \\
\hline Ammonium nitrogen & Markus et al. (1985) & \\
\hline Nitrate nitrogen & Markus et al. (1985) & \\
\hline
\end{tabular}




\section{RESULTS AND DISCUSSION}

\section{Performance of lysimeter}

\section{Settlement of the lysimeter}

Fig. 2 shows the settlement characteristics of straw in the lysimeter. Settlement of wastes can be a result of series of mechanisms like introduction of liquid into waste, including lubrication of contacts in the waste, softening of flexible porous materials, increasing the unit weight of the waste, and biodegradation (Benson et al., 2006). Typically, with the placement of waste in the lysimeter, initial settlement was high due to re-arrangement of waste skeleton. It was observed that the quantity settled was proportional to the leachate circulated.

In the first week, leachate recirculation was at a lower rate than the second and third weeks. The rate was $50 \mathrm{~L} \mathrm{day}^{-1}$ in the first week, then increased to $100 \mathrm{~L} \mathrm{day}^{-1}$. Removing $2 \mathrm{~L}$ of leachate and $5 \mathrm{~L}$ of fresh water did not effect the settlement. Then again, $90 \mathrm{~L}$ of leachate were removed on the $35^{\text {th }}$ day and $130 \mathrm{~L}$ of leachate were removed on $37^{\text {th }}$ day. However, on the $36^{\text {th }}$ day, $75 \mathrm{~L}$ of fresh water were added to stimulate the gas production. Nevertheless, high amount of leachate removal affected settlement. After 45 days, settlement did not change. It was due to the lack of recirculation events and adding of fresh water. Leachate recirculation helped promoting the waste settlement by allowing the leaching of hydrolyzed wastes into the bottom part of the lysimeters. The leaching of hydrolyzed wastes created higher porosity within the waste layer and the settlement took place once leachate had been drained out from the lysimeters.

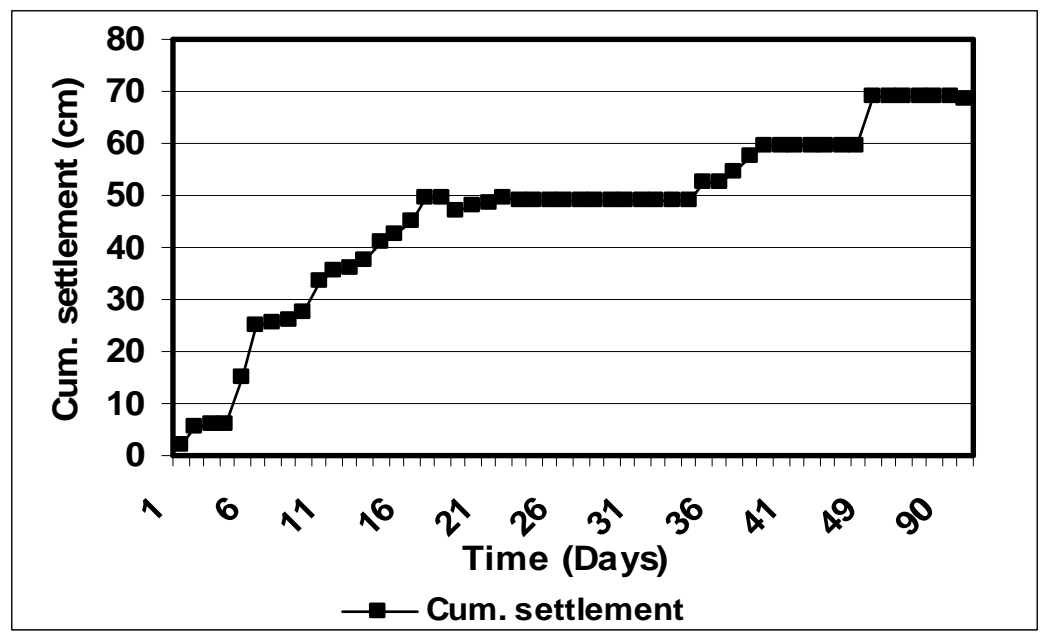

\section{Fig. 2. Variation of settlement in the lysimeter}

\section{Gas production}

Degradation of the solid waste in a landfill bioreactor enhances the landfill gas production and increases the methane production with time. Fully anaerobic condition and the leachate head at bottom of the reactor may be influence landfill gas production (Karunarathne, 2007). In this reactor, gas production increased in the first four days and it gradually decreased and 
ceased after 23 days. After 34 days, gas production recommenced and increased. This may be attributed to $\mathrm{pH}$ variation in the leachate. The $\mathrm{pH}$ range from 7-8 is favorable for the methonogenic bacteria (Benson et al., 2006). Acidogenic bacteria would have produced organic acids, which tend to lower the $\mathrm{pH}$ of the bioreactor. Methanogenic activities would have taken place in the acidogenic phase within microenvironments that were undergoing methanogenic phase reactions. In this study, the initial $\mathrm{pH}$ was 6 and it gradually decreased to 5.1. Therefore, an attempt was made to increase the $\mathrm{pH}$ by replacing a portion of leachate by fresh water. Then the $\mathrm{pH}$ gradually increased to 7.25 , thus, increasing the gas production (Fig. 3).

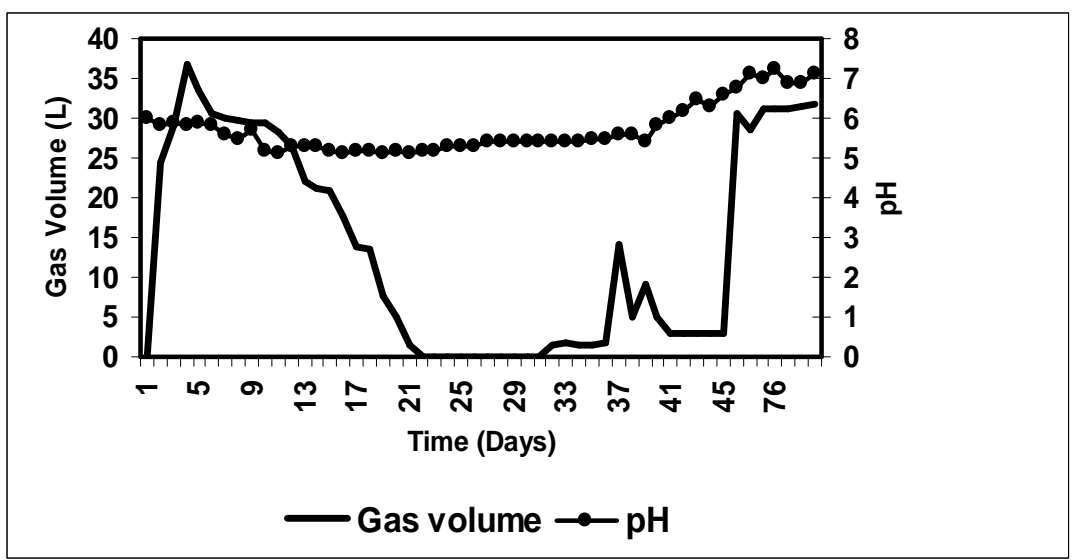

Fig. 3. Variation of $\mathrm{pH}$ and gas emission from the lysimeter.

\section{Variation of temperature and hydraulic conductivity}

It is evident that the temperature of the gas chamber fluctuated due to the environmental temperature variations. Middle temperature remained steady and sometimes gradually increased. Bottom temperature did fluctuate occasionally but with little variation. It was around $30{ }^{\circ} \mathrm{C}$. This may be due to the saturation of the bottom layer with water. A temperature between $32{ }^{\circ} \mathrm{C}$ and $35{ }^{\circ} \mathrm{C}$ was shown to be the most efficient for stable and continuous production of methane. The hydraulic conductivity values were very low permeating through the liner. It was effective in the mineralization and the purification of the leachate.

\section{Quantity of leachate}

Leachate is a significant component in landfill bioreactors affecting the degradation of waste by enhancing favorable conditions for microbial growth. In addition, it has a noteworthy effect on landfill gas production (Karunarathne, 2007). In the lysimeter simulation of the paddy straw landfill bioreactor, anaerobic conditions prevailed. The quantity of leachate in the lysimeter did stimulate anaerobic conditions. Inevitably, the amount of leachate in the reactor had increased the hydrolysis reactions. This increase in hydrolysis caused a decrease in $\mathrm{pH}$ and thus affected the gas production. Initially, water was a good medium to compress the straw, thus, $1704 \mathrm{~L}$ of water were added to the lysimeter, which gave a $2.3 \mathrm{~m}$ leachate head above the liner. Furthermore, to increase the $\mathrm{pH}$ from the 5.1 to $5.4,5 \mathrm{~L}$ of fresh water was added while $2 \mathrm{~L}$ of leachate were removed. The removal of leachate and adding of freshwater was repeated similar to the section of settlement of the lysimeter and results are shown in Fig. 4. 


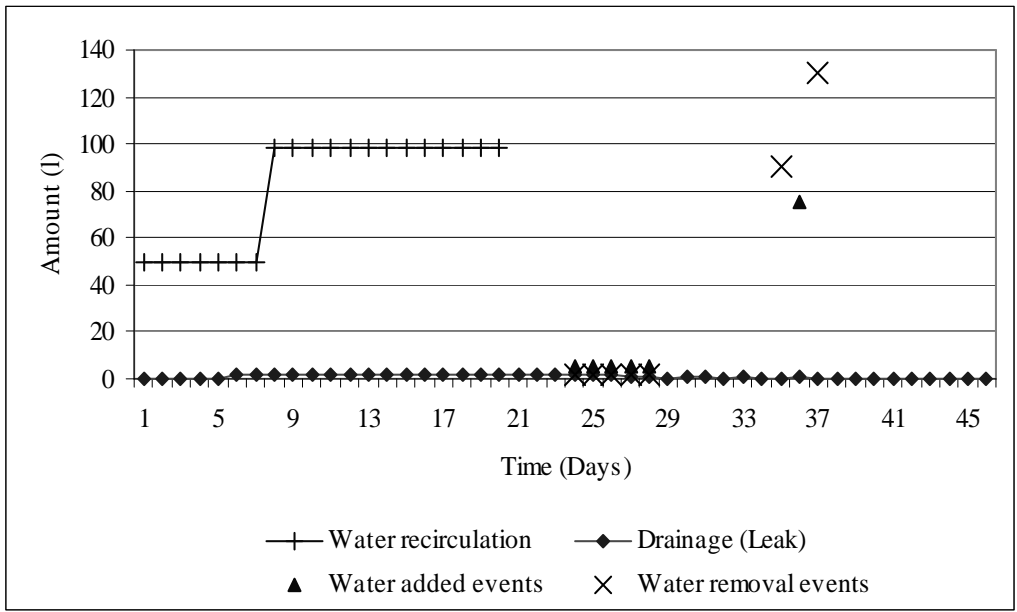

Fig. 4. Adjustment of leachate content in the lysimeter

\section{Leachate quality}

\section{Variation of electrical conductivity (EC) and total dissolved solids (TDS)}

The variations of the EC and TDS in leachate are shown in Fig. 5. Both TDS and EC varied in a similar manner and both gradually decreased until the $49^{\text {th }}$ day. The reduction of TDS indicates the utilization of TDS for bacteria. When there was a change in the TDS, EC also followed the same change. Towards the end of the study period, both of these parameters increased, promoting gas productions.

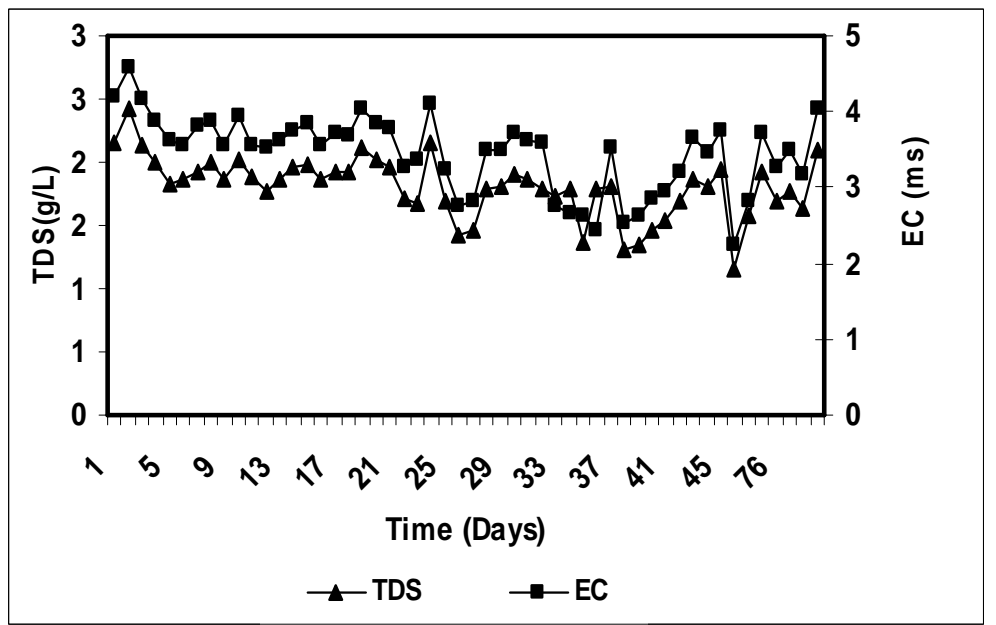

Fig. 5. Variation of Electrical Conductivity and Total Dissolved Solids in leachate 


\section{Variation of total solids (TS) and volatile solids (VS)}

The TS content did not vary significantly. Nevertheless, the VS gradually decreased with time. Both parameters showed a cyclic pattern of variation. This phenomenon may be due to the mineralization of inorganic components in the biomass. Increased concentration of inorganic components (ash) becomes toxic to microbes, but due to the effect of liner system, mineralization takes place and control the accumulation of ash (Fig. 6).

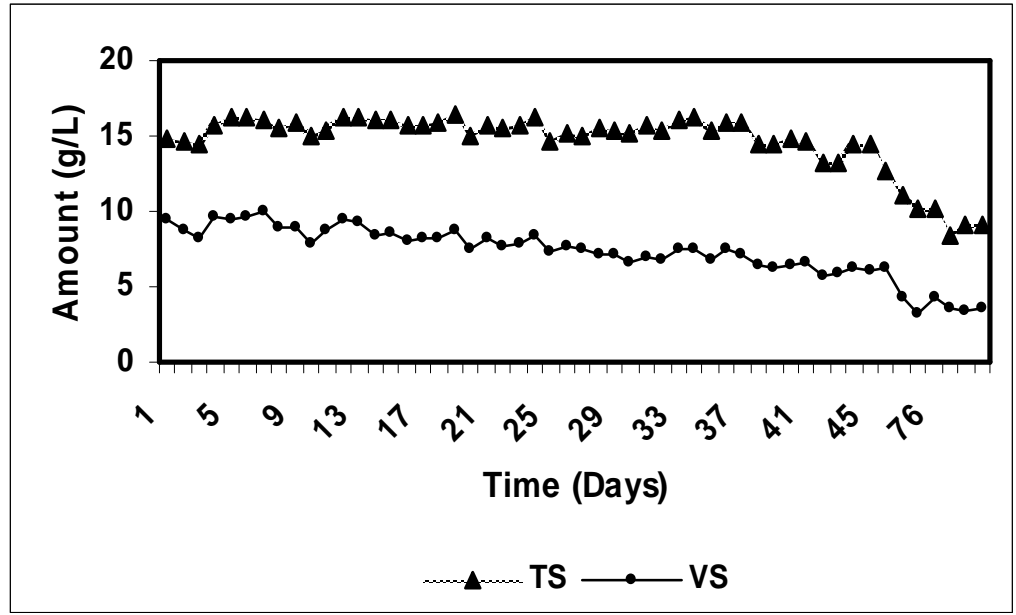

Fig. 6. Variation of total solids (TS) and volatile solids (VS) in leachate

Variations of total suspended solids (TSS), volatile suspended solids (VSS), total dissolved solids (TDS) and ash

Fig. 7 shows cumulative curves for TSS, VSS and TDS. The VSS represents the bacterial growth. Therefore, TSS variations show a cyclic behavior. The VSS also followed a similar cyclic pattern. In fact, it is possible to identify three cycles in this graph. The difference between TSS and VSS can account for ash. When the microbial growth increases, VSS concentration increased. After death of the microbes, VSS decreased. In the next cycle of the microbial growth, VSS once again increased.

When the microbial growth varied, inevitably, the degradation of organic matter also varied. Therefore, the TSS variations showed a similar pattern to VSS variations. In fact, TDS also changed in a similar manner, since hydrolysis and acidogenic reactions on converting solids to dissolved substrate depended on microbial activities. 


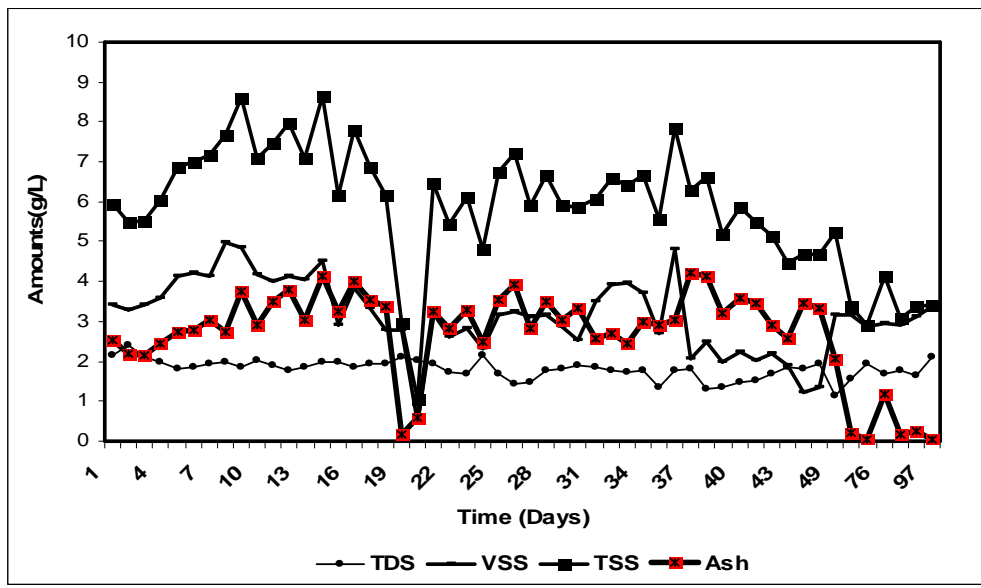

Fig. 7. Variations of cumulative total suspended solids (TSS), volatile suspended solids (VSS), total dissolved solids (TDS) and ash in leachate

\section{Variation of BOD, Organic carbon (OC) and sugar content (Brix)}

Fig. 8 shows the variation of the BOD, OC and Brix concentrations in the reactor. Biochemical Oxygen Demand notably indicates how much of dissolved oxygen can be used by microorganisms in the biological oxidation of organic matter for a specific duration and as standard, five days (Mata-Alvarez, 2003). Biochemical Oxygen Demand increased in the first 14 days and gradually decreased thereafter until 49 days. Then the BOD increased from 49 days to 63 days and gradually decreased after 63 days. This could be attributed to the $\mathrm{pH}$ variation in the leachate and microbial activity in the leachate. The BOD values of leachate varied with time and ranged from 0 to $10980 \mathrm{mg} \mathrm{L}^{-1}$. The BOD concentrations decreased after 63 days. This may be due to slow release and hydrolysis of organics from the straw into leachate and lack of recirculation may also have contributed to reducing the anaerobic process. During the experimental period, organic carbon content and Brix gradually decreased. Microbial decomposition of organic carbon and sugar content influences microbial activity and BOD

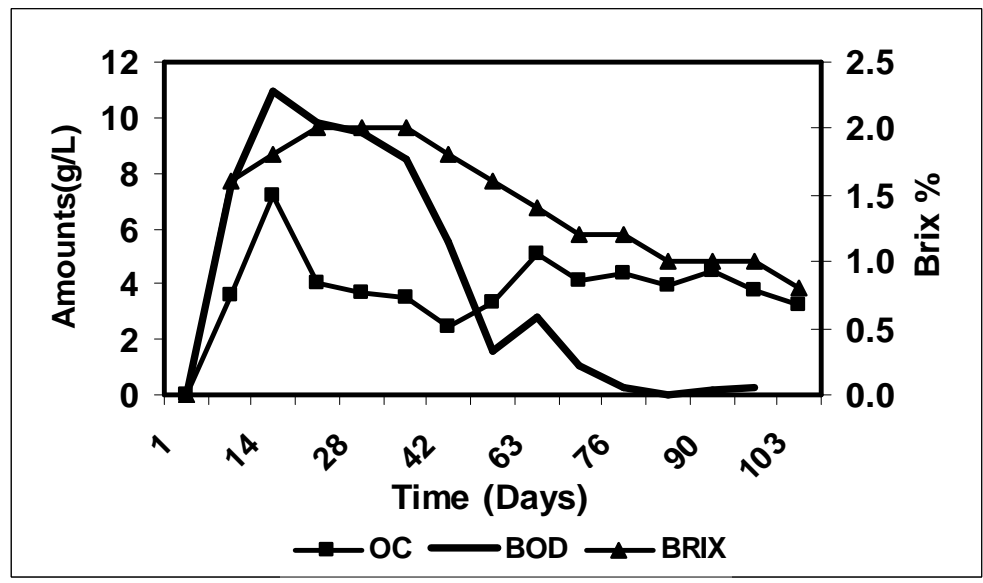

Fig. 8. Variation of BOD, Organic carbon (OC) and sugar content (BRIX) in leachate 


\section{Nitrate nitrogen $\left(\mathrm{NO}_{3}{ }^{-} \mathrm{N}\right)$ and ammonium nitrogen $\left(\mathrm{NH}_{4}{ }^{+}-\mathrm{N}\right)$}

Microbial decomposition of organic carbon influences many processes of the nitrogen cycle. With time, nitrogen concentration decreased due to microbial utilization of nitrate compounds and denitrifying as ammonia gas (Wu et al., 2006). Nitrate nitrogen and ammonium nitrogen showed similar variation trends (Fig. 9). Nitrate nitrogen increased to 60 $\mathrm{mg} \mathrm{L}^{-1}$ during the first 35 days and decreased gradually to $21.6 \mathrm{mg} \mathrm{L}^{-1}$ and again increased. The $\mathrm{NH}^{+}{ }_{4}-\mathrm{N}$ concentration of the leachate was lower than $\mathrm{NO}_{3}{ }^{-} \mathrm{N}$. After day 76, the $\mathrm{NH}_{4}{ }^{+}-\mathrm{N}$ and $\mathrm{NO}_{3}{ }^{-} \mathrm{N}$ concentrations decreased gradually. As reported by Hartmann et al., (2003) ammonia accumulation takes place and subsequently reduced. It may be a result of toxicity which affects microbial activity and ceases the gas production. Landfill leachate treatment is normally focused on the removal of organic matter and nitrogen, with little attention paid to the changes in toxicity during treatment. Toxicity is a consequence of numerous contaminants in leachate, their synergistic or antagonistic effects and different physicochemical properties and toxicity tests may thus give more information about leachate quality than do chemical analysis alone. Both biological and physical-chemical methods have been applied to remove chemical oxygen demand (COD) and ammonia-nitrogen $\left(\mathrm{NH}_{4}{ }^{+}-\mathrm{N}\right)$ from landfill leachates (Zhimin et al., 2009) (Fig. 9).

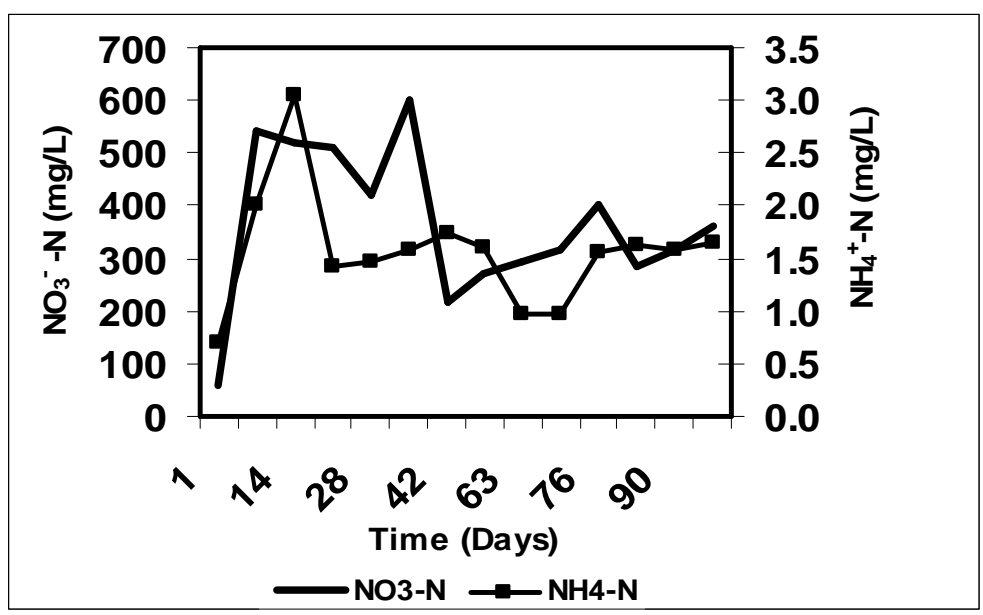

Fig. 9. Variation of $\mathrm{NO}_{3}{ }^{-}-\mathrm{N}$ and $\mathrm{NH}_{4}{ }^{+}-\mathrm{N}$ in leachate

\section{CONCLUSIONS}

The biogas production of the lysimeter fluctuated when compared to previous studies done on the same experimental site in the University of Peradeniya. Production of biogas during the study period was substantial. Maximum gas productions were recorded during the second and third weeks of experimentation. However, after the third week, gas emissions ceased due to $\mathrm{pH}$ reduction and the accumulation of leachate above the middle clay layer. This affected negatively on the biogas movement inside the lysimeter. Both fresh water addition and the removal of existing leachate gave positive effects to the gas production. The settlement of the lysimeter occurred rapidly due to low compaction and recirculation of leachate. The settlement indicated the biodegradation and physical movement of material in the lysimeter. Leachate of the lysimeter was a better indicator of biodegradation. It also provided the basis for understanding landfill bioreactor dynamics. The variations of TS and VS were indicative 
parameters of the conversion of complex organic compounds into soluble organic molecules in hydrolysis reactions. TSS and VSS gradually increased in a cyclic pattern due to changes in the microbial population within the lysimeter. The BOD concentrations decreased after 63 days and this may be due to slow release and hydrolysis of organics from the straw into leachate and lack of recirculation may also have contributed to reduce the anaerobic process. During the experimental period, organic carbon content and sugar content (Brix) gradually decreased. Microbial decomposition of organic carbon and sugar content did influence microbial activity and BOD. After 100 days, gas production was very low due the toxicity effects of $\mathrm{NO}_{3}{ }^{-}-\mathrm{N}$ or $\mathrm{NH}_{4}{ }^{+}-\mathrm{N}$. To overcome this effect adding fresh water was necessary. The simulated lysimeter performed satisfactorily. Therefore, the next step is to evaluate the performance of a landfill bioreactor 'Test Cell'.

\section{REFERENCE}

Benson, C.H. Barlaz, M.A. Lane, D.T. and Rawe J.M. (2006). Practice review of five bioreactor/recirculation landfills. Waste Mgt. 27: 13-29.

Champaign, E.T., Bet, K.L., Vinyard, B.T., Mc Clung, A.M., Barton, F.E., Moldenhauer, K., Linscombe, S. and Mc Kenzie, K. (1999). Correlation between cooked rice texture and rapid visco analysis measurements, Cereal Che. 76: 764-771.

Department of Census and Statistics (2008). http://www.statistics.gov.lk/agriculture

Gunarathna H.A.Y.R., Kapukotuwa A.S.B., Karunarathna A.K. and Basnayake B.F.A. (2007). Construction and Evaluation of a Low Cost, Wasted Polyethylene Based Liner for small Landfills. In: Proceedings International Conference on Solid Waste Management, Chennai, India, 5-7.

Hartmann, H. Angelidaki, I. and Ahring, B.K. (2003). Co- digestion of the organic fraction of municipal waste with other waste types. Ed. Mata- Alvarez, J. Biomethanaization of the organic fraction of municipal solid wastes, IWA, UK, pp. 21-58.

Karunarathne, S.K. (2007). Evaluation of MSW landfill bioreactor optimum gas production, B.Sc Research Report (unpublished), Department of Agricultural Engineering, Faculty of Agriculture, University of Peradeniya, Sri Lanka.

Markus, D.K., McKinnon, J.P. and Buccafuri, A.F. (1985). Automated analysis of nitrite, nitrate and ammonium nitrogen in soils. Soil Sci. Soc. Am. J. 49: 1208-1215.

Mata-Alvarez, J. (2003). Bioremethanization of the organic fraction of municipal solid waste. IWA publishing, Cornwall, UK. pp 1-17.

Nelson, D.W. and Sommers, L.E. (1982). Total carbon, organic carbon and organic matter. In Methods of soil analysis. Part 2. $2^{\text {nd }}$ ed. Agronomy no. 09, American Society of Agronomy, Madison, WI, USA.

Schutz, H., Holzapfel-Pschorn, A., Conrad, R., Rennenberg, H. And Seiler, W. (1989). A three year continuous record on the influence of day time, season, and fertilizer treatment on methane emission rates from an Italian rice paddy field. J. Geophys. Res. 94: 16405-16416. 
Warith, M., Li, X. and Jin, H. (2005). Bioreactor landfills: State-of-the-Art-Review. Envtl. J. for Engi. 10(1): 1-14.

Wickramasinghe, W. M.A.D.B. and Wijewardena, J.D.H. (2003). Soil fertility management and integrated plant nutrition systems in rice cultivation. Rice Congress 2000, Department of Agriculture, Peradeniya, Sri Lanka. pp. 125-140.

Wijewardena, J.D.H. (1993). Effect of organic and chemical fertilizers on vegetable cultivation in up-country intermediate zone. Trop. Agriculturist 149: 1-11.

Wijewardena, J.D.H. (2000). Comparison of animal manure sources on potato and vegetable cultivation in the up-country. ASDA, Department of Agriculture, Sri Lanka, 2: 357-369.

Wu, D., Quan, X., Zhang, Y. and Zhao, Y. (2006). Long-term operation of a compost-based biofilter for biological removal of $n$-butyl acetate, $p$-xylene and ammonia gas from an air stream. Bioche. Engi. J. 32(2): 84-92.

Yagi, K. and Minami, K. (1990). Effects of organic matter application on methane emission from some Japanese paddy fields. Soil Sci. Plant Nutr. 36: 599-610.

Zhimin F., Fenglin, Y., Yingyu, A., and Yuan, X. (2009). Characteristics of nitrite and nitrate in situ denitrification in landfill bioreactors. Bioreso. Techno. 100: 3015-3021. 